\title{
Immobilization of $\alpha$-Chymotrypsin on the Surface of Magnetic/Gold Core/Shell Nanoparticles
}

\author{
Mahmoud Kamal Ahmadi ${ }^{1}$ and Manouchehr Vossoughi ${ }^{2}$ \\ ${ }^{1}$ Department of Chemical and Biological Engineering, State University of New York at Buffalo, 303 Furnas Hall, Buffalo, \\ NY 14260-4200, New York, USA \\ ${ }^{2}$ Department of Chemical and Petroleum Engineering, Sharif University of Technology, Azadi Avenue, P.O. Box 11365, Tehran, Iran
}

Correspondence should be addressed to Mahmoud Kamal Ahmadi; mahmoudk@buffalo.edu

Received 23 July 2013; Accepted 10 October 2013

Academic Editor: E. Goldys

Copyright (C) 2013 M. Kamal Ahmadi and M. Vossoughi. This is an open access article distributed under the Creative Commons Attribution License, which permits unrestricted use, distribution, and reproduction in any medium, provided the original work is properly cited.

\begin{abstract}
Over the last decade, nanoparticles used as protein carriers have opened new avenues for a variety of biomedical applications. The main concern for these applications is changes in biological activity of immobilized proteins due to conformational changes on the surface of the carrier. To evaluate this concern, the preparation and biocatalyst activity of $\alpha$-chymotrypsin- $\mathrm{Fe}_{3} \mathrm{O}_{4} @ \mathrm{Au}$ core/shell nanoparticles were investigated. First, $\mathrm{Fe}_{3} \mathrm{O}_{4} @$ Au core/shell nanoparticles were synthesized by coprecipitation method and citrate reduction of $\mathrm{HAuCl}_{4}$. TEM imaging revealed a core size of $13 \pm 3 \mathrm{~nm}$ and a shell thickness of $4 \pm 1 \mathrm{~nm}$ for synthesized nanoparticles. $\mathrm{X}$-ray diffraction (XRD) was used to study the crystalline structure of the nanoparticles. Next, the enzyme was immobilized on the surface of synthesized nanoparticles by covalent bonding of Au shell with thiol and amine groups present in the protein structure (e.g., cysteine and histidine residues). FTIR and fluorescence spectroscopy were utilized to study secondary and tertiary structures of the immobilized enzyme. Results show that the secondary and tertiary structures of the enzyme remain virtually unchanged after immobilization on the nanoparticles surface. However, the biocatalyst activity of the enzyme was reduced by thirty percent, indicating possible conformational changes or active site occlusion.
\end{abstract}

\section{Introduction}

In the past decade, magnetic nanoparticles have been studied for their biomedical applications [1] such as cellular therapy $[2,3]$, drug delivery $[4,5]$, hyperthermia, and magnetic resonance imaging (MRI) $[6,7]$. While one can find a comprehensive discussion on critical factors for interaction of nanoparticles with living cell and proteins in reviews by Rauch et al. [8] and Mahmoudi et al. [9], it could be summarized that nanoparticles must have biocompatibility and interactive functions at the surface to allow their use in biomedical applications $[10,11]$. Both organic and inorganic coatings have been used for surface modification of magnetic nanoparticles $[10,12]$. Polyethylene glycol (PEG) and polyvinyl alcohol (PVA) are mainly used for polymeric surface modification [13, 14]. Silica and gold are the most common inorganic molecules used to modify the surfaces of magnetic nanoparticles [10,13]. A silica layer provides a rich surface of silanol groups that react easily with alcohols and silane coupling agents $[15,16]$. However, of the available surface modifiers, gold shows great potentials for biomedical applications [10]. Gold not only confers stability to nanoparticles in oxidative solutions but also aids binding of various biological ligands through gold-thiol and gold-amine chemistry $[17,18]$. Moreover, Au coating provides plasmonic properties which might be useful for some optical applications [19-21]. In spite of the aforementioned advantages of $\mathrm{Fe}_{3} \mathrm{O}_{4} @ \mathrm{Au}$ nanoparticles, they are used to a lesser extent than bare gold or magnetic nanoparticles, primarily due to the difficulty of core/shell nanoparticles synthesis procedure [22]. Nevertheless, core/shell nanoparticles have found their own applications among the works of literature.

Tamer and coworkers [22] used core/shell $\mathrm{Fe}_{3} \mathrm{O}_{4}-\mathrm{Au}$ nanoparticles for two different bioassays: fructose measurement based on boronic acid-activated magnetic nanoparticles and immunomagnetic separation of $E$. coli. Their experiment 
validated the use of magnetic/gold core/shell nanoparticles for the detection of biological molecules and for magnetic bioseparation. Moreover, Xie and coworkers [23] showed that modified $\mathrm{Fe}_{3} \mathrm{O}_{4} / \mathrm{Au}$ core/shell nanoparticles with $\mathrm{Ni}^{2+}$ nitrilotriacetic acid may be used for rapid, efficient, and specific enrichment and separation of His-Tag fusion proteins directly from mixture of cell lysis. More recently, Cui et al. [24] made orientally bioconjugated core/shell $\mathrm{Fe}_{3} \mathrm{O}_{4}$ @ Au magnetic through covalent attachment of anti-CD3 monoclonal antibody. They further used this bioconjugation technique for cell separation, demonstrating a separation efficiency of $98.4 \%$ of CD3+ T cells from whole splenocytes.

In this study, we investigated the production of chymotrypsin- $\mathrm{Fe}_{3} \mathrm{O}_{4} @ \mathrm{Au}$ core/shell bioconjugates and characterized their biocatalytic activity. Bioconjugates and synthesized nanoparticles were further characterized by UV-visible spectroscopy, transmission electron microscopy (TEM), and X-ray diffraction (XRD). Additionally, secondary and tertiary structures of the chymotrypsin protein were investigated qualitatively by FTIR and fluorescence spectroscopy, respectively, revealing a mostly unaltered structure for the immobilized enzyme. However, casein activity test showed a thirty percent decrease in biocatalytic activity of the immobilized enzyme compared to unbound enzyme.

\section{Materials and Methods}

All chemicals were obtained from commercial sources and used as received. $\mathrm{FeCl}_{3} \cdot 6 \mathrm{H}_{2} \mathrm{O}, \mathrm{FeSO}_{4} \cdot 5 \mathrm{H}_{2} \mathrm{O}$, sodium hydroxide, Triton X-100 (TX-100), sodium citrate, trichloroacetic acid (TCA), and casein were purchased from Merck, Germany. Hydrogen tetrachloroaurate hydrate and bovine $\alpha$ chymotrypsin (E.C. 3.4.21.1) were purchased from SigmaAldrich. Milli-Q water (Millipore) was used throughout. Aqua regia solution (1:3 nitric acid/hydrochloric acids) was applied to clean all glassware used in nanoparticles synthesis.

UV-visible spectra in range of $300-800 \mathrm{~nm}$ were collected on a Perkin Elmer, Lambda 95, two-beam UV-visible spectrophotometer using $1 \mathrm{~cm}$ path length quartz cuvettes. TEM images were captured on a Philips-CM10 $(100 \mathrm{kV})$. XRD measurements were performed on a Phillips PW $1800 \mathrm{X}$-ray diffraction system in the range of $2 \theta=0$ to 80 degrees. FTIR spectra were collected using a Tensor 27, Bruker Optics $\mathrm{GmbH}$. The fluorescence of the enzyme-nanoparticles bioconjugates was measured using a Cary Eclipse fluorescence spectrometer.

2.1. Synthesis of $\mathrm{Fe}_{3} \mathrm{O}_{4}$ Nanoparticles. Magnetic nanoparticles were prepared by coprecipitation of $\mathrm{Fe}(\mathrm{II})$ and $\mathrm{Fe}(\mathrm{III})$, with a $\mathrm{Fe}(\mathrm{II}) / \mathrm{Fe}$ (III) ratio of 0.5 (1) [10]. In addition, Triton $\mathrm{X}-100$ was used to introduce micelles. Briefly, $0.002 \mathrm{~mol}$ of $\mathrm{FeCl}_{3} \cdot 6 \mathrm{H}_{2} \mathrm{O}$ and $0.001 \mathrm{~mol}$ of $\mathrm{FeSO}_{4} \cdot 5 \mathrm{H}_{2} \mathrm{O}$ were dissolved in $100 \mathrm{~mL}$ of deionized water. To this solution, TX-100 was added to make a final Triton concentration of $0.0045 \mathrm{M}$. The solution was heated to $80^{\circ} \mathrm{C}$. Then $4 \mathrm{~mL}$ of $10 \mathrm{M} \mathrm{NaOH}$ solution was added rapidly with vigorous stirring using an ultrasonic stirrer probe under argon atmosphere. The temperature was maintained at approximately $80^{\circ} \mathrm{C}$, and stirring was continued for $30 \mathrm{~min}$ after the addition of $\mathrm{NaOH}$ solution. After this time, the heat source was removed, and the suspension was stirred at room temperature for another 2 hours using a mechanical stirrer to maximize surface adsorption of TX-100:

$$
\mathrm{Fe}^{2+}+2 \mathrm{Fe}^{3+}+8 \mathrm{OH}^{-} \longrightarrow \mathrm{Fe}_{3} \mathrm{O}_{4}+4 \mathrm{H}_{2} \mathrm{O}
$$

A black precipitate was collected on a permanent magnet and washed with deionized water three times. Finally, $\mathrm{Fe}_{3} \mathrm{O}_{4}$ nanoparticles were dispersed in DI water and used for further experiments.

2.2. Synthesis of $A u$ Shell. Gold coating was synthesized on the $\mathrm{Fe}_{3} \mathrm{O}_{4}$ nanoparticles using a method described previously [25] with some slight modifications. Briefly, a mixture of $5 \mathrm{~mL}$ of the magnetic suspension described above and $25 \mathrm{~mL}$ of $0.1 \% \mathrm{HAuCl}_{4}$ (i.e., $1 \mathrm{~g} /$ lit) was stirred vigorously for $30 \mathrm{~min}$. Then $35 \mathrm{~mL}$ of $0.1 \mathrm{M}$ sodium citrate was added dropwise. Stirring continued for another hour. In all steps, the temperature was maintained at approximately $50^{\circ} \mathrm{C}$. The resulting nanoparticle solution was reddish brown. Using a permanent magnet, nanoparticles were collected, and the supernatant was discarded. The washing procedure was repeated three times, and, finally, core/shell nanoparticles were dispersed in $100 \mathrm{~mL}$ of DI water to be used in further tests.

2.3. Formation of Chymotrypsin-Colloidal $\mathrm{Fe}_{3} \mathrm{O}_{4} @ \mathrm{Au}$ Nanoparticles. A $10^{-6} \mathrm{M}$ standard solution of the enzyme, $\alpha$-chymotrypsin (molecular weight $\sim 22500$, pI $\sim 7.8$ ), was prepared in PBS buffer $(0.1 \mathrm{M}, \mathrm{pH}=7.6)$. Different amounts of standard solution were added drop by drop to colloidal nanoparticles to yield various enzyme concentrations in the range of $5 \times 10^{-7}$ and $10^{-8} \mathrm{M}$ in the conjugate solution. Due to the optimum biocatalytic activity of chymotrypsin occurring at $\mathrm{pH}=7.6$, the $\mathrm{pH}$ of the colloidal $\mathrm{Fe}_{3} \mathrm{O}_{4} @ \mathrm{Au}$ nanoparticles was adjusted to 7.6 in advance. The solution was kept for a period of $12 \mathrm{~h}$ at $4^{\circ} \mathrm{C}$ and then centrifuged to remove uncoordinated enzyme from the solution. The powder obtained from the solution was rinsed several times with buffer and suspended in the $\mathrm{pH}=7.6$ buffer and then stored at $4^{\circ} \mathrm{C}$ for future use. It is reported that immobilization is based on the covalent attachment of thiol and amine groups to the Au surfaces $[26,27]$.

2.4. Measurement of Enzyme Activity. The biocatalytic activities of chymotrypsin and chymotrypsin-nanoparticles conjugates were determined by reaction with casein in PBS buffer at $\mathrm{pH}=7.6$ (see (2)) [28]. In a typical experiment $300 \mu \mathrm{L}$ of free protein or bioconjugate solution was reacted with $1 \mathrm{~mL}$ of casein solution (\% l), in a total reaction volume of $2 \mathrm{~mL}$. The mixture was incubated at $50^{\circ} \mathrm{C}$ (optimum temperature for chymotrypsin) for $20 \mathrm{~min}$ (results for 10-, 15- and 25-minute incubations are almost identical, not shown here). After the incubation, $1 \mathrm{~mL}$ of trichloroacetic acid $20 \%$ was added to the reaction solution to precipitate the residual casein. After $45 \mathrm{~min}$ the precipitate was removed by centrifugation, and 
the optical absorbance of the supernatant was measured at $280 \mathrm{~nm}$. The experiments were repeated three times to establish the reproducibility of the results:

$$
\text { Activity }=\frac{\mu \mathrm{g} \text { of tyrosine }}{\text { mg enzyme } \times \text { time }(\min )} .
$$

Chymotrypsin digests casein to yield soluble polypeptides including tryptophan and tyrosine residues, which can be detected by their strong UV absorbance at $280 \mathrm{~nm}$. Measured UV absorbance was related to mass of tyrosine produced by using a tyrosine standard calibration curve.

\section{Results and Discussion}

3.1. Characterization of the Core/Shell Nanoparticles. The $\mathrm{UV}$-visible absorption spectra of the dispersion of pure $\mathrm{Fe}_{3} \mathrm{O}_{4}, \mathrm{Fe}_{3} \mathrm{O}_{4} @ \mathrm{Au}$ core shell nanoparticles and synthesized bioconjugates are shown in the range of 400 to $700 \mathrm{~nm}$ in Figure 1. For bare $\mathrm{Fe}_{3} \mathrm{O}_{4}$ the absorption increases as the wavelength decreases, which has been reported previously $[22,29]$. However, after the fabrication of a gold shell, a peak can be observed at approximately $550 \mathrm{~nm}$, indicating the successful formation of a gold shell by the method described above. In addition attachment of enzyme is accomplished by a broadening and redshift of the plasmon resonance, which is related to the presence of chymotrypsin on the surface of the nanoparticles. The broadening of the plasmon resonance indicates degree of aggregation of the nanoparticles mediated by the protein molecules [22, 26, 27].

The size of synthesized nanoparticles was characterized by transmission electron microscopy (TEM). TEM micrograph (Figure 2(a)) shows that the average diameter of pure $\mathrm{Fe}_{3} \mathrm{O}_{4}$ was approximately $13 \pm 2 \mathrm{~nm}$. However, after modification of the core nanoparticles by addition of an Au shell, the particle size increased to $20 \pm 4 \mathrm{~nm}$. Therefore, the thickness of the $\mathrm{Au}$ shell was approximately $4 \mathrm{~nm}$. The thickness of the shell might be changed by varying the experimental parameters, especially the ratio of $\mathrm{HAuCl}_{4} / \mathrm{Fe}_{3} \mathrm{O}_{4}$, which is the most critical factor [30].

Crystalline structures of $\mathrm{Fe}_{3} \mathrm{O}_{4}$ and the core/shell nanoparticles were further examined by XRD. Figure 3 shows the XRD pattern of the synthesized nanoparticles. The experimentally obtained patterns were identified by comparison with standard $\mathrm{Fe}_{3} \mathrm{O}_{4}$ and $\mathrm{Au}$ patterns. Figure 3(a) shows the XRD pattern of the synthesized $\mathrm{Fe}_{3} \mathrm{O}_{4}$ nanoparticles. This pattern shows characteristic peaks at $2 \theta=30.3,35.2,43.1$, $56.9,62.8$, and 74.3. These peaks are indicative of the pure face-centered cubic structure of $\mathrm{Fe}_{3} \mathrm{O}_{4}$, with a dominant crystal plane of 111 [31]. Figure 3(b) shows the XRD pattern of the nanoparticles after being coated with gold. Peaks at $2 \theta=31.6,38.1,44.4,64.5$, and 77.4 are assigned to the AuFe position and indicate the formation of gold coat on the surface of the iron oxide magnetic nanoparticles $[22,30]$.

\subsection{Characterization of the Enzyme-Nanoparticle Bioconju-} gate. To enable proper biocatalyst activity, the secondary and tertiary structures of protein should remain essentially unchanged after immobilization on the surface. Though

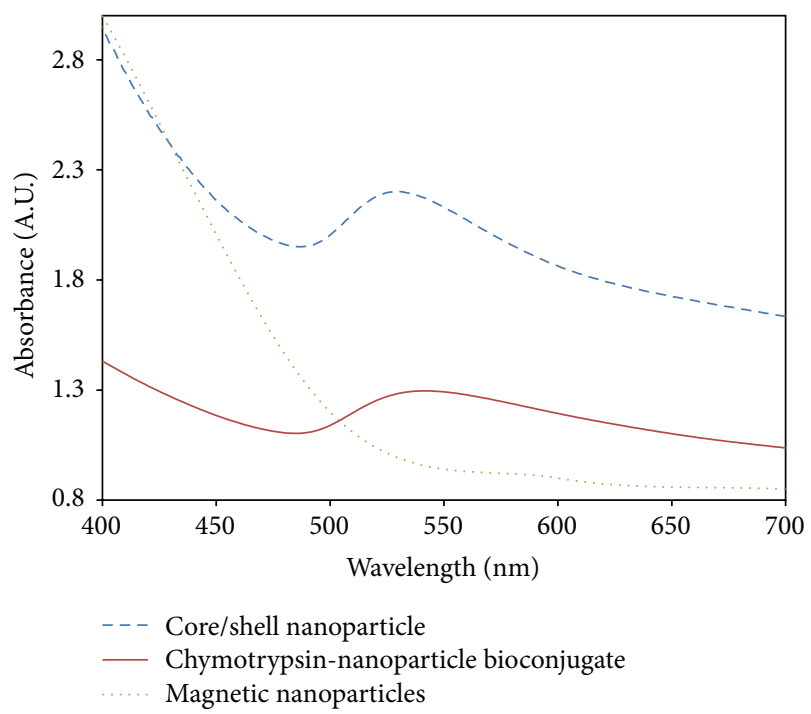

FIgURE 1: UV-visible spectra of bare synthetic $\mathrm{Fe}_{3} \mathrm{O}_{4}$ nanoparticles and $\mathrm{Fe}_{3} \mathrm{O}_{4} @ \mathrm{Au}$ core/shell nanoparticles along with the spectrum of chymotrypsin bioconjugates. Concentration to prepare bioconjugates was $2 * 10^{-7} \mathrm{M}$. A redshift (approximately $15 \mathrm{~nm}$ ) can be observed.

FTIR can be used for the quantitative study of proteins secondary structure, it was used here only to obtain qualitative information about the secondary structure. The amide linkages between amino acid residues in polypeptides and proteins produce well-known signatures in FTIR spectra. The positions of amide I and amide II bands in the FTIR spectra of proteins are sensitive indicators of conformational changes in the secondary structure $[26,27]$. The amide I band is assigned to the stretch mode of the carbonyl group coupled to the amide linkage, and the amide II band arises due to $\mathrm{N}-\mathrm{H}$ vibration in the amide [26, 27, 32].

Figure 4 shows the FTIR spectra of nanoparticles before and after conjugation. Different stretching and bending modes give rise to various peaks in the specified range. A broadband at approximately 3445 is assigned to the stretch of the $\mathrm{N}-\mathrm{H}$ bonds in the enzyme. This band could also represent $\mathrm{O}-\mathrm{H}$ vibrations from trapped water molecules in the enzyme-nanoparticles bioconjugate film. Two small features at approximately 2800 to 3000 are assigned to the methylene asymmetric and symmetric vibrations of the hydrocarbons present in the enzymes. The peaks at 1636 and 1410 result from $\mathrm{C}=\mathrm{O}$ stretching of the amide I and amide II bands, respectively. Moreover, peaks in the range of 850 to 1260 are assigned to $\mathrm{C}-\mathrm{H}$ and $\mathrm{C}-\mathrm{N}$ stretching in the aryl structure of amino acids residues, such as histidine.

The biocatalytic activity of the enzyme largely depends on its tertiary structure, which ideally should remain unchanged when the enzyme is immobilized on the surface of the core/shell nanoparticles. The standard procedure for studying tertiary structure of enzymes involves measuring fluorescence emission from the tryptophan or tyrosine residues in the enzyme [33]. In this study, the tertiary structure of the immobilized enzyme was studied by excitation of 


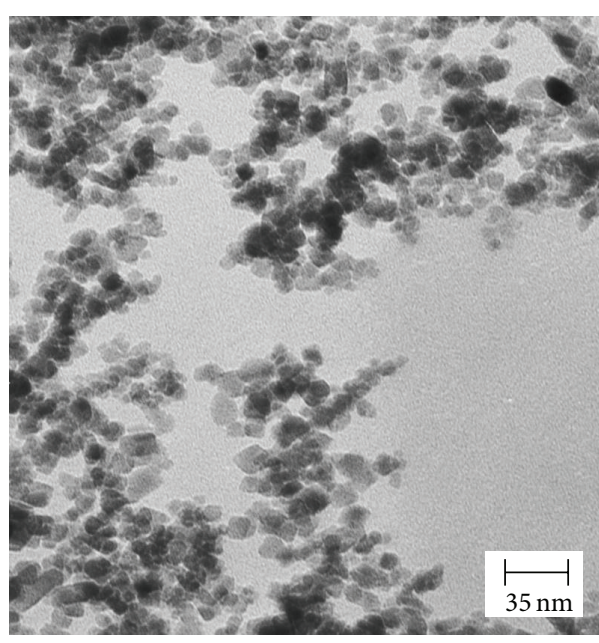

(a)

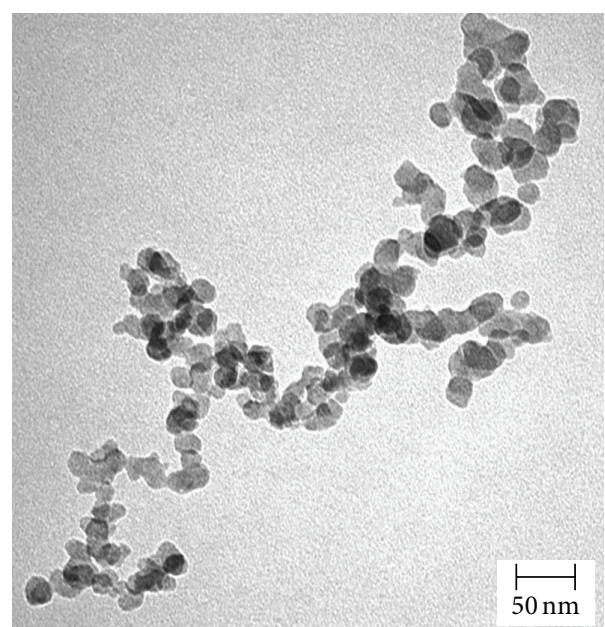

(b)

Figure 2: TEM images of pure $\mathrm{Fe}_{3} \mathrm{O}_{4}$ core nanoparticles (a) and $\mathrm{Fe}_{3} \mathrm{O}_{4}$ @ Au core/shell nanoparticles (b).

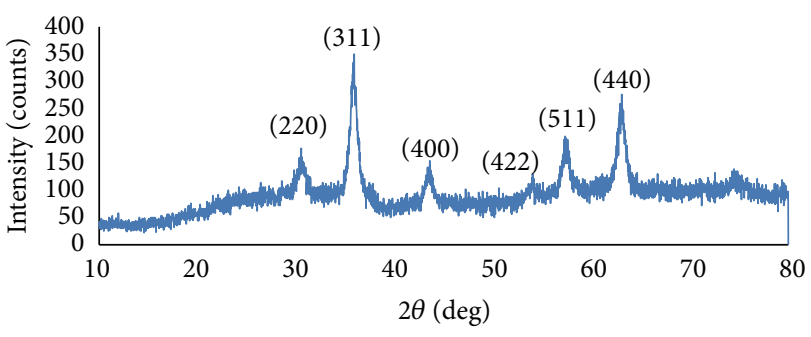

(a)

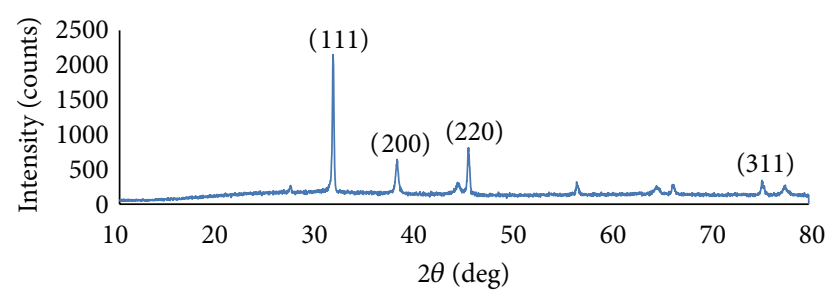

(b)

FIgURE 3: XRD pattern of synthesized pure $\mathrm{Fe}_{3} \mathrm{O}_{4}$ (a) and $\mathrm{Fe}_{3} \mathrm{O}_{4} @ \mathrm{Au}$ core/shell nanoparticles (b).

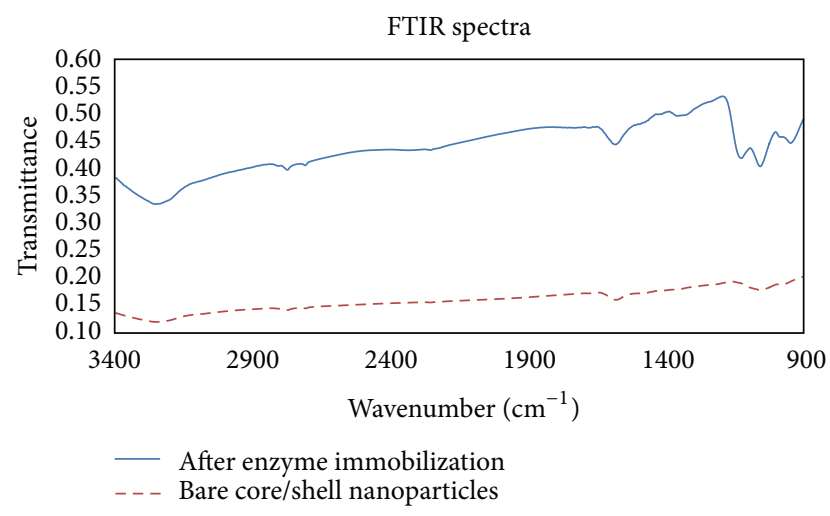

FIGURE 4: FT-IR spectra of $\mathrm{Fe}_{3} \mathrm{O}_{4} @$ @ Au nanoparticles before (a) and after enzyme immobilization (b). Final concentration of enzyme for bioconjugates formation was $2 \times 10^{-7} \mathrm{M}$.

the $\pi-\pi^{*}$ transition in the tryptophan or tyrosine residues at $280 \mathrm{~nm}$.

Figure 5 shows the fluorescence spectra recorded for a $2 \times 10^{-7} \mathrm{M}$ buffer solution of free enzyme at $\mathrm{pH}=7.6$, as well as the fluorescence spectra of $2 \times 10^{-7} \mathrm{M}$ and $5 \times$ $10^{-8} \mathrm{M}$ bioconjugate solution (these are final concentrations of added enzyme in nanoparticles' solutions; see Section 2.3). As the figure shows, the intensities of the absorbance maxima show small shifts, but the maximum occurs at approximately $350 \mathrm{~nm}$ in all four solutions. This finding indicates that the enzyme molecules retain their natural configuration well and that their tertiary structures are nearly the same when immobilized as in free solutions. The fluorescence spectra of PBS buffer and bare nanoparticles were also studied by excitation at $280 \mathrm{~nm}$. For these two controls, we observe no emission in the range considered.

Fluorescence spectroscopy results also can be used to measure the amount of chymotrypsin present in the bioconjugate solution by comparing the intensity of the maximal emission (i.e., the emission at $350 \mathrm{~nm}$ ) with the standard calibration curve [27]. The calibration curve was obtained by plotting the fluorescence intensities of different concentrations of enzyme in PBS buffer. Concentration of enzyme in the bioconjugate assay was determined to be $4 \times 10^{-8} \mathrm{M}$ for the $2 \times 10^{-7} \mathrm{M}$ starting solution. Consequently, an important parameter for estimation of specific activity of the bioconjugate solution, for three random sets of experiments involving protein not immobilized in the supernatant and washing, was measured (absorbance assay at $280 \mathrm{~nm}$ ), and by difference calculation with initial enzyme concentrations the reliability of the fluorescence results was confirmed to extent. 


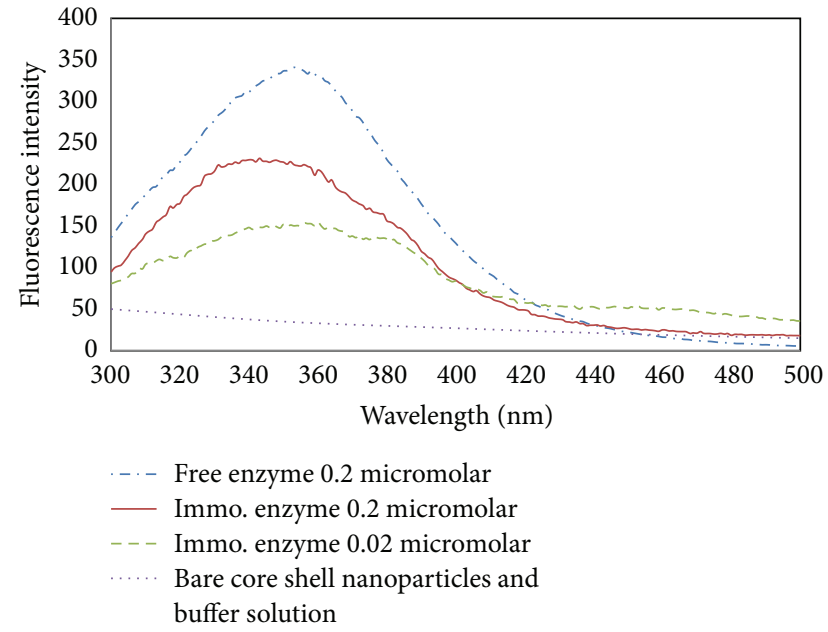

FIGURE 5: Fluorescence spectra of free enzyme solution $(0.2 \mu \mathrm{M})$ and two bioconjugates' solution are shown. Final concentrations of enzyme for immobilizations were $0.2 \mu \mathrm{M}$ and $0.02 \mu \mathrm{M}$. Spectra of bare nanoparticles suspension in PBS buffer are also shown as control.

3.3. Biocatalytic Activity. Having determined the concentration of the immobilized enzyme based on the fluorescence data and the amount of tyrosine produced based on the UV assay (Section 2.4), estimation of biocatalyst activity of the immobilized enzymes can be performed using (2). For comparison, biocatalytic activity of an identical concentration of free enzyme was recorded. For example, for the aforementioned case of a $2 \times 10^{-7} \mathrm{M}$ starting solution (that produced a $4 \times 10^{-8} \mathrm{M}$ immobilized enzyme concentration; see Section 3.2) the activity of the chymotrypsin-nanoparticle bioconjugate was calculated to be $903 \pm 10$ units while the activity was $1280 \pm 10$ units for free enzyme with the same concentration. Thus, the activity of chymotrypsin was reduced by approximately $30 \%$ after immobilization on the surface of $\mathrm{Fe}_{3} \mathrm{O}_{4} @ \mathrm{Au}$ core/shell nanoparticles.

As mentioned, we observed a decrease in enzyme activity; however, contradictory results have been reported for systems of different enzymes and nanoparticles in the work of the literature. The immobilization of pepsin and fungal protease on the surface of $4 \mathrm{~nm}$ gold nanoparticles [26, 27] and the immobilization of glucose oxidase on $20 \mathrm{~nm}$ gold nanoparticles caused almost no changes in the activities of the enzymes [34]. The activity of chymotrypsin decreases by 50 percent after immobilization on $10 \mathrm{~nm}$ bare $\mathrm{Fe}_{3} \mathrm{O}_{4}$ magnetic nanoparticles [35]. The activity of lipase also decreases upon immobilization on the surface of gamma- $\mathrm{Fe}_{3} \mathrm{O}_{4}$ nanoparticles [36]. On the other side, it has been reported that the attachment of cholesterol oxidase to magnetic nanoparticles increases the stability and activity of the enzyme [37]. Stabilization of $\alpha$-chymotrypsin by covalent immobilization on the amine-functionalized magnetic nanogel yielded in $40 \%$ loss of activity, while the immobilized enzyme had better resistance to temperature and $\mathrm{pH}$ inactivation in comparison to free enzyme [38]. By consideration of protein coronas and cell vision one might explain the conflictory results reported for dissimilar nanoparticles-protein systems [39-41].

There are many factors that might influence conformation, activity, and live length of absorbed protein coronas on surface of nanoparticles. Size, shape, surface charge and curvature, solubility, and composition of nanoparticles all might affect nature of protein binding to the surface of nanoparticles [41]. Effect of these parameters on protein absorption will be more critical as one passes from modelistic in vitro systems to realistic in vivo where protein concentration and system complexity are quite significant $[40,42,43]$. For a full discussion on influential factors in protein-nanointeraction, one might refer to decent review by Mahmoudi and coworkers [41]. In addition to protein coronas, safe design of nanoparticles in regard to nanotoxicology is another crucial factor to be considered in design and usage of any nanoparticle-based systems for biomedical applications. Of more interest is the fact that uptake and defense mechanism of living cells toward the same nanoparticles could differ from a cell line to another, a concept best described by the term "cell vision" [44]. For instance, Mahmoudi and coworkers used MTT assay and a DNA microarray analysis to study effect of superparamagnetic iron oxide nanoparticles with various surface modifications $\left(\mathrm{COOH}\right.$, plain, and $\left.\mathrm{NH}_{2}\right)$ through the comparison with gene expression patterns of three cell types (human heart, brain, and kidney). They found that not only surface groups but also the cell type can have a significant role in the definition of suitable pathways for detoxification of exogenous nanoparticles [45]. Besides importance on nanotoxicology, attention to cell vision, along with protein coronas, is vital to get a better understanding on interaction of nanoparticles in biological systems [39, 45].

While some of the mentioned parameters are of high importance for complex biological serum, on a simple system of one protein in a buffer and one specific nanoparticle, effect of nanoparticles' features will be more profound [41]. Such that, the observed decrease in chymotrypsin bioactivity can be explained by several phenomena. The likely critical factor is conformational change experienced by the enzyme upon attachment to the surface of the nanoparticles (loosely indicated by small horizontal shift in fluorescence spectra, Figure 5). This conformational change occurs most probably because of the surface curvature [32, 41]. The weight of this factor increases with aggregation of nanoparticles and particle size increases [46, 47]. Aggregation also inhibits substrate diffusion to the enzyme active site [41]. In addition, chymotrypsin contains histidine residues in its active site leading to potential binding of its catalytic site. If that happens, it will decrease the biocatalyst activity of the enzyme [32]. However, the first factor is more likely the dominant reason for this decrease in activity $[26,27,32]$.

\section{Conclusion}

$\alpha$-Chymotrypsin- $\mathrm{Fe}_{3} \mathrm{O}_{4} @$ Au core/shell nanoparticles bioconjugates have been prepared by the addition of the enzyme to colloidal nanoparticles at the proper $\mathrm{pH}$. The formation of such bioconjugates is based on the covalent binding of 
thiol groups in the cysteine residues and amine groups in the lysine or histidine residues of the enzyme to the gold surface. FT-IR and fluorescence studies indicate that the secondary and tertiary structures of the enzyme remained unperturbed when bound on the surface of nanoparticles. However, estimation of the biocatalytic activity of the enzyme showed a $30 \%$ decrease in activity for the immobilized enzyme, as compared to the free enzyme. Conformational changes and the direct binding of the enzyme's active site to the surface could be the two main reasons for this decrease. Additional nanoparticles surface modifications and reductions in the size of the nanoparticles may help to enhance the activity of immobilized enzyme.

\section{References}

[1] A. Wu, P. Ou, and L. Zeng, "Biomedical applications of magnetic nanoparticles," Nano, vol. 5, no. 5, pp. 245-270, 2010.

[2] S. M. Moghimi, A. C. Hunter, and J. C. Murray, "Long-circulating and target-specific nanoparticles: theory to practice," Pharmacological Reviews, vol. 53, no. 2, pp. 283-318, 2001.

[3] J. M. Wilkinson, "Nanotechnology applications in medicine," Medical Device Technology, vol. 14, no. 5, pp. 29-31, 2003.

[4] Y. Zhang, N. Kohler, and M. Zhang, "Surface modification of superparamagnetic magnetite nanoparticles and their intracellular uptake," Biomaterials, vol. 23, no. 7, pp. 1553-1561, 2002.

[5] X. Su, X. Zhan, F. Tang, J. Yao, and J. Wu, "Magnetic nanoparticles in brain disease diagnosis and targeting drug delivery," Current Nanoscience, vol. 7, no. 1, pp. 37-46, 2011.

[6] M. G. Harisinghani, J. Barentsz, P. F. Hahn et al., "Noninvasive detection of clinically occult lymph-node metastases in prostate cancer," New England Journal of Medicine, vol. 348, no. 25, pp. 2491-2499, 2003.

[7] J. He, H. F. VanBrocklin, B. L. Franc, Y. Seo, and E. F. Jones, "Nanoprobes for medical diagnosis: current status of nanotechnology in molecular imaging," Current Nanoscience, vol. 4, no. 1, pp. 17-29, 2008.

[8] J. Rauch, W. Kolch, S. Laurent, and M. Mahmoudi, "Big signals from small particles: regulation of cell signaling pathways by nanoparticles," Chemical Reviews, vol. 113, pp. 3391-3406, 2013.

[9] M. Mahmoudi, H. Hofmann, B. Rothen-Rutishauser, and A. Petri-Fink, "Assessing the in vitro and in vivo toxicity of superparamagnetic iron oxide nanoparticles," Chemical Reviews, vol. 112, no. 4, pp. 2323-2338, 2012.

[10] A. K. Gupta and M. Gupta, "Synthesis and surface engineering of iron oxide nanoparticles for biomedical applications," Biomaterials, vol. 26, no. 18, pp. 3995-4021, 2005.

[11] A. Jordan, R. Scholz, K. Maier-Hauff et al., "Presentation of a new magnetic field therapy system for the treatment of human solid tumors with magnetic fluid hyperthermia," Journal of Magnetism and Magnetic Materials, vol. 225, no. 1-2, pp. 118-126, 2001.

[12] X. Zhou, S. Ni, X. Wang, and F. Wu, "Adsorption of sodium oleate on nano-sized $\mathrm{Fe} 3 \mathrm{O} 4$ particles prepared by co-precipitation," Current Nanoscience, vol. 3, no. 3, pp. 259-263, 2007.

[13] A. K. Gupta and S. Wells, "Surface-modified superparamagnetic nanoparticles for drug delivery: preparation, characterization, and cytotoxicity studies," IEEE Transactions on Nanobioscience, vol. 3, no. 1, pp. 66-73, 2004.

[14] J. Lee, T. Isobe, and M. Senna, "Preparation of ultrafine Fe3O4 particles by precipitation in the presence of PVA at high $\mathrm{pH}$,"
Journal of Colloid and Interface Science, vol. 177, no. 2, pp. 490494, 1996.

[15] S. Santra, R. Tapec, N. Theodoropoulou, J. Dobson, A. Hebard, and W. Tan, "Synthesis and characterization of silica-coated iron oxide nanoparticles in microemulsion: the effect of nonionic surfactants," Langmuir, vol. 17, no. 10, pp. 2900-2906, 2001.

[16] A. Ulman, "Formation and structure of self-assembled monolayers," Chemical Reviews, vol. 96, no. 4, pp. 1533-1554, 1996.

[17] E. E. Carpenter, "Iron nanoparticles as potential magnetic carriers," Journal of Magnetism and Magnetic Materials, vol. 225, no. 1-2, pp. 17-20, 2001.

[18] J. Lin, W. Zhou, A. Kumbhar et al., "Gold-coated iron (Fe@Au) nanoparticles: synthesis, characterization, and magnetic fieldinduced self-assembly," Journal of Solid State Chemistry, vol. 159, no. 1, pp. 26-31, 2001.

[19] Z. Xu, Y. Hou, and S. Sun, "Magnetic core/shell $\mathrm{Fe}_{3} \mathrm{O}_{4} / \mathrm{Au}$ and $\mathrm{Fe}_{3} \mathrm{O}_{4} / \mathrm{Au} / \mathrm{Ag}$ nanoparticles with tunable plasmonic properties," Journal of the American Chemical Society, vol. 129, no. 28, pp. 8698-8699, 2007.

[20] G. K. Kouassi, "Magnetic and gold-coated magnetic iron oxide nanoparticles as detection tools: preparation, characterization, and biosensing applications," Current Nanoscience, vol. 7, no. 4, pp. 510-523, 2011.

[21] D. Wu, X.-D. Zhang, P.-X. Liu, L.-A. Zhang, F.-Y. Fan, and M.-L. Guo, "Gold nanostructure: fabrication, surface modification, targeting imaging, and enhanced radiotherapy," Current Nanoscience, vol. 7, no. 1, pp. 110-118, 2011.

[22] U. Tamer, Y. Gündoğdu, I. H. Boyaci, and K. Pekmez, "Synthesis of magnetic core-shell Fe3O4-Au nanoparticle for biomolecule immobilization and detection," Journal of Nanoparticle Research, vol. 12, no. 4, pp. 1187-1196, 2010.

[23] H.-Y. Xie, R. Zhen, B. Wang, Y.-J. Feng, P. Chen, and J. $\mathrm{Hao}$, "Fe3O4/au core/shell nanoparticles modified with $\mathrm{Ni}^{2+}$ nitrilotriacetic acid specific to histidine-tagged proteins," Journal of Physical Chemistry C, vol. 114, no. 11, pp. 4825-4830, 2010.

[24] Y.-R. Cui, C. Hong, Y.-L. Zhou, Y. Li, X.-M. Gao, and X.$\mathrm{X}$. Zhang, "Synthesis of orientedly bioconjugated core/shell $\mathrm{Fe}_{3} \mathrm{O}_{4} @$ Au magnetic nanoparticles for cell separation," Talanta, vol. 85, no. 3, pp. 1246-1252, 2011.

[25] W. Wu, Q. He, H. Chen, J. Tang, and L. Nie, "Sonochemical synthesis, structure and magnetic properties of air-stable $\mathrm{Fe}_{3} \mathrm{O}_{4}$ /Au nanoparticles," Nanotechnology, vol. 18, no. 14, Article ID 145609, 2007

[26] A. Gole, C. Dash, V. Ramakrishnan et al., "Pepsin-gold colloid conjugates: preparation, characterization, and enzymatic activity," Langmuir, vol. 17, no. 5, pp. 1674-1679, 2001.

[27] A. Gole, C. Dash, C. Soman, S. R. Sainkar, M. Rao, and M. Sastry, "On the preparation, characterization, and enzymatic activity of fungal protease-gold colloid bioconjugates," Bioconjugate Chemistry, vol. 12, no. 5, pp. 684-690, 2001.

[28] M. L. Kakade, D. H. Swenson, and I. E. Liener, "Note on the determination of chymotrypsin and chymotrypsin inhibitor activity using casein," Analytical Biochemistry, vol. 33, no. 2, pp. 255-258, 1970.

[29] L.-L. Pang, J.-S. Li, J.-H. Jiang, Y. Le, G. L. Shen, and R.-Q. Yu, “A novel detection method for DNA point mutation using QCM based on $\mathrm{Fe}_{3} \mathrm{O}_{4} / \mathrm{Au}$ core/shell nanoparticle and DNA ligase reaction," Sensors and Actuators B, vol. 127, no. 2, pp. 311-316, 2007.

[30] M. Mandal, S. Kundu, S. K. Ghosh et al., "Magnetite nanoparticles with tunable gold or silver shell," Journal of Colloid and Interface Science, vol. 286, no. 1, pp. 187-194, 2005. 
[31] J. Sun, S. Zhou, P. Hou et al., "Synthesis and characterization of biocompatible Fe3O4 nanoparticles," Journal of Biomedical Materials Research A, vol. 80, no. 2, pp. 333-341, 2007.

[32] M.-E. Aubin-Tam and K. Hamad-Schifferli, "Structure and function of nanoparticle-protein conjugates," Biomedical Materials, vol. 3, no. 3, Article ID 034001, 2008.

[33] M. R. Eftink and C. A. Ghiron, "Fluorescence quenching studies with proteins," Analytical Biochemistry, vol. 114, no. 2, pp. 199227, 1981.

[34] D. Li, Q. He, Y. Cui, L. Duan, and J. Li, "Immobilization of glucose oxidase onto gold nanoparticles with enhanced thermostability," Biochemical and Biophysical Research Communications, vol. 355, no. 2, pp. 488-493, 2007.

[35] M. Koneracká, P. Kopčanský, M. Antalík et al., "Immobilization of proteins and enzymes to fine magnetic particles," Journal of Magnetism and Magnetic Materials, vol. 201, no. 1-3, pp. 427430, 1999.

[36] A. Dyal, K. Loos, M. Noto et al., "Activity of Candida rugosa lipase immobilized on $\gamma$ - $\mathrm{Fe}_{2} \mathrm{O}_{3}$ magnetic nanoparticles," Journal of the American Chemical Society, vol. 125, no. 7, pp. 16841685,2003

[37] G. K. Kouassi, J. Irudayaraj, and G. McCarty, "Examination of cholesterol oxidase attachment to magnetic nanoparticles," Journal of Nanobiotechnology, vol. 3, article 1, 2005.

[38] J. Hong, P. Gong, D. Xu, L. Dong, and S. Yao, "Stabilization of $\alpha$-chymotrypsin by covalent immobilization on aminefunctionalized superparamagnetic nanogel," Journal of Biotechnology, vol. 128, no. 3, pp. 597-605, 2007.

[39] S. Laurent, C. Burtea, C. Thirifays, U. O. Häfeli, and M. Mahmoudi, "Crucial ignored parameters on nanotoxicology: the importance of toxicity assay modifications and 'cell vision," PLoS ONE, vol. 7, no. 1, Article ID e29997, 2012.

[40] A. Lesniak, F. Fenaroli, M. P. Monopoli, C. Åberg, K. A. Dawson, and A. Salvati, "Effects of the presence or absence of a protein corona on silica nanoparticle uptake and impact on cells," ACS Nano, vol. 6, pp. 5845-5857, 2012.

[41] M. Mahmoudi, I. Lynch, M. R. Ejtehadi, M. P. Monopoli, F. B. Bombelli, and S. Laurent, "Protein-nanoparticle interactions: opportunities and challenges," Chemical Reviews, vol. 111, no. 9, pp. 5610-5637, 2011.

[42] M. P. Monopoli, D. Walczyk, A. Campbell et al., "Physicalchemical aspects of protein corona: relevance to in vitro and in vivo biological impacts of nanoparticles," Journal of the American Chemical Society, vol. 133, no. 8, pp. 2525-2534, 2011.

[43] D. Walczyk, F. B. Bombelli, M. P. Monopoli, I. Lynch, and K. A. Dawson, "What the cell "sees" in bionanoscience," Journal of the American Chemical Society, vol. 132, no. 16, pp. 5761-5768, 2010.

[44] M. Mahmoudi, S. N. Saeedi-Eslami, M. A. Shokrgozar et al., "Cell, "vision": complementary factor of protein corona in nanotoxicology," Nanoscale, vol. 4, pp. 5461-5468, 2012.

[45] M. Mahmoudi, S. Laurent, M. A. Shokrgozar, and M. Hosseinkhani, "Toxicity evaluations of superparamagnetic iron oxide nanoparticles: cell "vision" versus physicochemical properties of nanoparticles," ACS Nano, vol. 5, no. 9, pp. 7263-7276, 2011.

[46] M. P. Klein, M. R. Nunes, R. C. Rodrigues et al., "Effect of thesupport size on the properties of $\beta$-galactosidase immobilized on chitosan: advantages and disadvantages of macro and nanoparticles," Biomacromolecules, vol. 13, pp. 2456-2464, 2012.

[47] M.-E. Aubin-Tam, W. Hwang, and K. Hamad-Schifferli, "Sitedirected nanoparticle labeling of cytochrome c," Proceedings of the National Academy of Sciences of the United States of America, vol. 106, no. 11, pp. 4095-4100, 2009. 

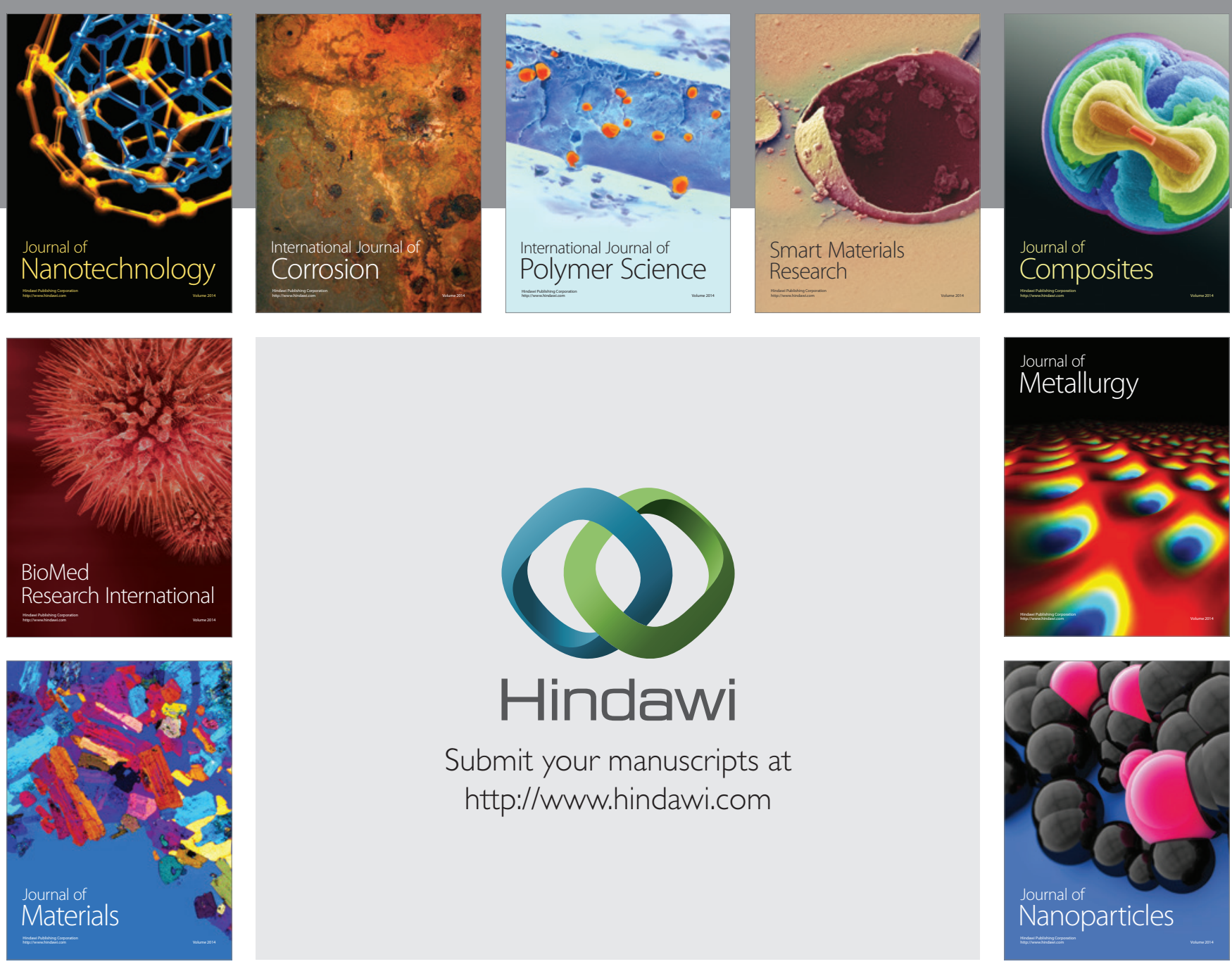

Submit your manuscripts at http://www.hindawi.com
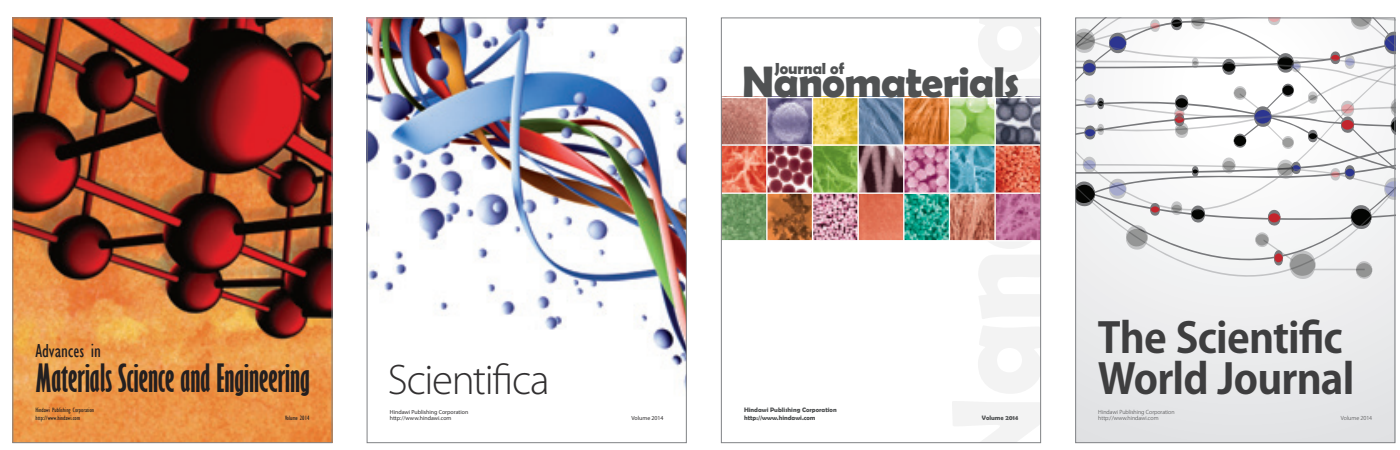

\section{The Scientific World Journal}
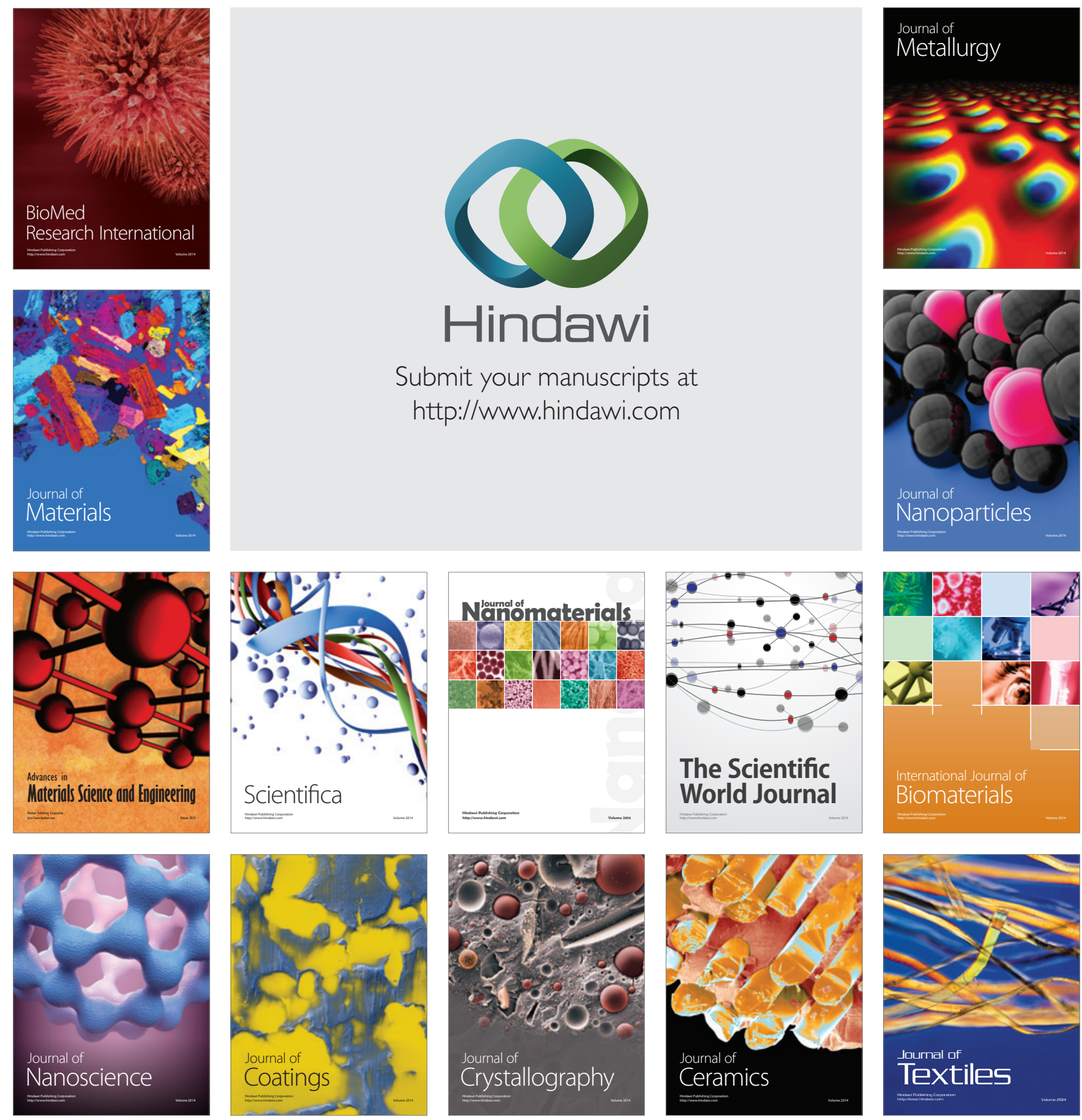